\title{
Parathyroid Gland Clear Cell Adenoma
}

National Cancer Institute

\section{Source}

National Cancer Institute. Parathyroid Gland Clear Cell Adenoma. NCI Thesaurus. Code C7993.

A parathyroid gland adenoma composed predominantly of neoplastic cells with clear cytoplasm. 